Dave Laing

\title{
Resource notes
}

Dave Laing is Associate Editor of Popular Music History and Visiting Research Fellow, School of Music, University of Liverpool.
27 Hiley Road

London NW10 5PT, UK

dave.laing47@gmail.com

\section{Center for Black Music Research}

The Center for Black Music Research (CBMR) was established in 1983 by the eminent scholar Samuel A. Floyd Jr. The title and thesis of his book, The Power of Black Music (1995) and that of the Black Music Research Journal echo the mission statement of the CBMR. That statement distinguishes between 'black' and 'AfricanAmerican', terms which are often used interchangeably:

in the CBMR's lexicon, African-American music emanates directly from the black experience in the United States. Black music, on the other hand, is music in any style or genre composed by people of African descent-including European and European-derived concert-hall music by black composers-as well as vernacular musics created and performed by African-descended people the world over, including African-American music, African music, and Afro-Latin American or Afro-Caribbean music.

The CBMR is based at Columbia College, Chicago, where it has ten full-time staff. The heart of the Center is its library and archives which was established in 1990 and opened to scholars, researchers and members of the public two years later. The library now contains over 5,000 books and dissertations, 11,000 sound recordings in all disc and tape formats and over 4,000 scores and sheet music copies.

A particular feature of the CBMR archives is over 70 collections donated by individuals and organizations. These vary widely in size and range of content. In addition to manuscripts, letters and written records, these include audiovisual recordings, oral history interviews, photographs, documentary films and ephemera.

Among the important figures in the field of black music studies whose archives have been deposited with the CBMR are Eileen Southern, Gerhard Kubik and Kenneth M. Bilby. The Southern collection includes original photographs and

\section{eøuinoxonline}


interviews as well as a file of letters from W. C. Handy to the African-American composer William Grant Still. Kubik's collection contains a sampling of field research materials from his ethnomusicological work in Angola, Cameroon and Mozambique in the 1960s. The Bilby material is an oral history programme of taped interviews with 100 Jamaican studio musicians, arrangers and singers who created the ska, rocksteady and reggae genres.

The archives also include the research collections of writers and academics Martin T. Williams and Charles Hamm. Williams was a leading jazz critic in the 1960s and 1970s, who directed jazz and American culture programmes at the Smithsonian Institution throughout the 1970s. He donated all of his jazzrelated materials to the CBMR before his death in 1992, including a large collection of recordings available for onsite listening. The Charles Hamm materials pertain mainly to Hamm's research on South African popular music during the early 1980 s.

An unusual collection donated by professional organizations is that of the Bo Diddley Track programme. This originated in 1993 when two blues-loving gerontologists decided that their profession should recognize the achievements of, and problems faced by, elderly blues musicians. Therefore, they organized sessions at the annual meetings of the American Society on Aging and the Gerontological Society of America where musicians from the city hosting the conference would talk and perform. The programme was named after the musician who participated in one of the earliest sessions, in San Francisco in 1994. As well as Bo Diddley, participants have included Sandra Hall, Sunnyland Slim, Roscoe Gordon and David 'Honeyboy' Edwards. The collection includes sound and video recordings plus printed materials.

The CBMR has an extensive publications programme. It produces the Black Music Research Journal, a newsletter CBMR Digest and a series of monographs. The Center co-publishes the book series Music of the African Diaspora with the University of California Press. Edited by Guthrie P. Ramsey, the series now contains 15 titles. In 2010, the CBMR established a parallel programme of CD releases, in collaboration with Albany Records. The first titles in this Recorded Music of the African Diaspora consist of new recordings of concert music by African American composers such as Olly Wilson and Florence B. Price. It is intended that future releases will include rereleases as well as field recordings of black music from around the world.

Another facet of CBMR activity is the organization of conferences on black music research, often in conjunction with other scholarly organizations. These have included the Society for Ethnomusicology, the College Music Society and the Society for American Music. 
Since its inception, the CBMR has received funding from the Rockefeller Foundation and a number of other foundations and agencies. It remains, however, a department of Columbia College and, early in 2012, a report on the future of the college recommended that Columbia should no longer support the CBMR. This provoked numerous protests from within and beyond the black music community and the CBMR was subsequently 'reinstated' by the trustees of Columbia College. Those interested in following developments should monitor the CBMR webpage at http://www.colum.edu/CBMR/. 